Journal of Economics and Behavioral Studies

Vol. 3, No. 3, pp. 185-189, Sep 2011 (ISSN: 2220-6140)

\title{
Exploring the Leadership Terrain: Reflections from Literature
}

\author{
${ }^{*}$ Sami Ullah Bajwa1 ${ }^{1}$ Qamar Ali², Khalid Hafeez Shahryar ${ }^{3}$ \\ ${ }^{1}$ Small and Medium Enterprises Development Authority, Government of Pakistan \\ ${ }^{2}$ Government College University Faisalabad, Pakistan \\ ${ }^{3}$ Health Department, Government of Punjab, Pakistan \\ *samibajwa@hotmail.com
}

\begin{abstract}
This paper appraises the available literature on concept of leadership and proposes fresh imputes to the mainstream theory by highlighting five facets of leadership. First, leadership and management are interlinked yet distinctive set of knowledge and practice-which are not substitution to each other. Second, leadership gets instigated with making of leader's self and its solicitation of authenticity by the followers. Third, an intimate relationship between leader and followers is deemed necessary for embarking on motivation and inspiration among followers to pursue established goals, even if they apparently seem unachievable. Fourth, contemporary organization study overwhelmingly posits leadership as individualistic domain, and thus fails to spot due diligence on the scope of co-leadership. Fifth, whilst talking high of leadership, we must not overlook the potential drawbacks that leadership might augment, because-like all other power corridors-leadership does have this tendency of fostering personal and sometimes ill-conceived agendas.
\end{abstract}

Key Words: Leadership, inspiration, self, shared leadership, downsides of leadership.

\section{Introduction}

Leadership is a phenomenon that pertains to influence individuals so that they could contribute towards group goals on one hand and coordinate the pursuit of those goals on the other (Bass, Bass, \& Bass, 2008; Hollander, 1992). It is one of the extensively researched areas and there is general consensus among practitioners and theorists that leaders play a decisive role in fortifying effectiveness, and hence success, in various echelons of organizations (Gillespie \& Mann, 2004). This paper takes insights from literature and attempts to outline a rather holistic scope of leadership in an organizational context by presenting views about five distinctive realms of leadership theory. Accordingly, the paper delineates leadership in comparison to management, individual self of leader, inspiration and support, potential downsides of leadership, and tasks of a leader in organizational perspective. In principle, effort has been made to coalesce different dimensions of leadership so that a cohesive illustration of the concept could be manifested.

\section{Management versus Leadership}

There is a longstanding distinction between management and leadership in the organization studies. (Yukl \& Yukl, 2002). One way of viewing this distinction can be the different sources of motivation for these two forms of authority. Leadership, most apparently, works through the connections that people feel to the social groups like teams, organizations and institutions etc, while management works through the pain and pleasure principle. In other words, leaders' authority is utilized through their words and behavior in an effort to convince employees about the vision that they carry with them for the future of the organization, whereas managers use inducements along with other control mechanisms as fine instruments of their authority to make employees do what they want them to do. For that reason, we see that leaders tend to demonstrate social qualities such as ability to communicate enthusiasm and vision, a positive outlook, intuitive insight and emotional capacity, whereas management is generally described as a process of working with and through human and other resources for achieving organizational goals (Ashkanasy, Härtel, \& Zerbe, 2000).

These variations make both, leadership and management, indispensible for certain organizational functions. Leadership is deemed more appropriate at the outset when an enterprise is being conceived or created (Bjerke \& Hultman, 2003), at times when change and transformation is required (Kotter \& gestion, 1995) and 
it tends to be most critical at times of crisis (Van Vugt, Hogan, \& Kaiser, 2008). Whereas, management is most appropriate in day to day handling of operations within the organization, for the smooth performance of systems and processes which ensure sustainability of organization (Kotter, 2001). The focus of a leader is outside the organization whereas focus of a manger is always inside the organization. Metaphorically speaking, the leader is just like a driver of a vehicle, who guides and controls the vehicle towards its destination while all the time looking outside the vehicle, whereas manager is just like a care taker who ensures the proper functioning of all the parts of the vehicle and its smooth operations.

Neither management nor leadership is appalling; and furthermore, none of them is replacement of each other. However, management in separation from leadership can lead to disaster in any organizational setting as it is clear from $20^{\text {th }}$ century debacles. Owing to the lessons learned during this course, organizations are now increasingly viewing leadership as their competitive advantage and therefore are investing in its development (Fulmer, 1998; McCall, 1998). It has been observed that management functions tend to resist change and they make people stick to the status quo. That's why application of management, in absence of leadership, makes it difficult to change and transform organizations and hinders the creation of new enterprises (Eisenbach, Watson, \& Pillai, 1999). Once it is established that that leadership is all about persuasion and inspiration rather than authority and control, it is quite possible for leadership to flow upward, downward and sideways even without being in a position of legitimate power within a team (Keys \& Wolfe, 1988).

Making of a Leader's Self: Leadership starts with a leader's self. For leaders to have credibility, they must have a persona, a character and a unique identity (Lord, De Vader, \& Alliger, 1986). In other words, leaders must help others see the kind of self they are. Furthermore, leader's depicted self must be real one because people like to be led by real people and therefore it is critical for a leader to find a style of leadership he/she is comfortable with (Ng, Ang, \& Chan, 2008).

Leaders, as a matter of fact, develop their personalities as foundation of their leadership. There are number of leadership styles that can be developed successfully. One of such personality styles-as showed by a recent meta analysis study on Big Five personality dimensions-'extraversion' is most related to leadership emergence and effectiveness ratings (Judge, Bono, Ilies, \& Gerhardt, 2002). Once leaders succeed in building a strong and sustainable self image, they aspire to develop authenticity by their consistent behavior (Gardner, Avolio, Luthans, May, \& Walumbwa, 2005). If leaders' actions are contradictory to the developed perception, it will lead to lack of authenticity and failure in return. Once authenticity is established leaders need to focus on the development of capabilities to lead the team. A leader is capable if he or she is expert and creative and if he or she is able to epitomize the core values of the team to create a fit. Moreover, a clear and inspiring vision is needed for a leader to be capable to lead effectively. Expertise involve, of course, understanding what the team is doing and what its surroundings are like. Leaders need to be mindful about the options and issues facing the team. Creativity and innovation are result of this approach towards the situation of the team.

Inspiration \& Support: A leader who provides guidance to followers, treats them fairly, and encourages their participation is said to be a supportive leader (House \& Mitchell, 1974). Leaders must focus on the importance of developing strong ties with others in the team - upward, downward and sideways. This area of leadership rests on the interpersonal ties that feel honest, accessible and human. It has been empirically testified that style of leader and his or her engagement with the team members are positively related to the team learning, knowledge application, and subsequently performance of these teams (Sarin \& McDermott, 2003). Leaders need to show concern for others in the team, give respect regardless of positions, and should understand the needs and capabilities of others. It has been observed that intimate relationship between leader and team significantly improves job performance, satisfaction with supervision, overall satisfaction, commitment, role clarity, member competence, and abates turnover intentions.(Gerstner \& Day, 1997) Leaders have to build a desire for greatness or excellence by raising expectations and motivating the team or organization to accept challenges, and by raising enthusiasm and confidence at the same time. Leader's ability to motivate employees, in fact, has been of major interest for many researchers (Landy \& Becker, 1987). A recent study reiterated this understanding that leaders cultivate social bonding among organizational members which ultimately augments feelings of vigor and motivations at work place (Carmeli, Ben-Hador, Waldman, \& Rupp, 2009). 
Leaders' charisma, arguably, does not remain the only source of inspiration, any longer. The prevailing complexity in contextual and structural dimensions of organizations stipulates the need of vigorously pursuing employee's sense of possible by articulating persuasively how the seemingly unrealistic and unattainable is possible and worth pursuing. Leaders inspire their teams by facilitating the establishment of challenging goals and by getting their people to do their level best, to be their best selves (House, 1971). If leader makes it clear that he or she is having high expectations from the team, then the team will obviously exert outstanding efforts to find creative solutions to the problems it encounters as it strives to meet or exceed leader's expectations.

Leadership involves making others aware of organizational problems and simultaneously making they secure in their own capacity to look at the problem, act rationally, and take appropriate action. Leaders need to provide necessary resources and autonomy to employees so that a sense of acceptance, security and efficacy could be fashioned. Among various characteristics of the effective leaders, their tendency to empower subordinates carries a special importance as it has been observed as consistent to the high level of team performance. (Townsend \& Bennis, 1997). Effective leadership also involves ensuring that employees have the training, resources, and encouragement necessary to reach the challenging goals. Leadership involves a personal realization that a team or organization involves deeply held community values and that the highest calling of the leader is to honor and protect those values. There is a public role of leadership which requires leaders to represent their teams (Kozlowski, Gully, Salas, \& Cannon-Bowers, 1996). So, leaders need to behave in ways that enact the team values and bring credit to the leader and to the team and organization.

Shared Leadership: Shared leadership is required whenever a corporation deals with very complex and critical challenges which demand a level of skills beyond a single person's capacity (Pearce \& Barkus, 2004). Shared leadership is often seen as counterproductive and leadership is supposed to be an individual act. Leadership, whenever discussed, draws our attention towards the classics such as Mohandas Gandhi. One can easily refer that throughout the independence struggle of India, Jinnah, Nehru and Patel accompanied Gandhi, and without their joint effort Gandhi would have not been able to get it to a success. (O Toole, Galbraith, \& Lawler, 2002). However, the dilemma in contemporary theory is to study, teach and refer leadership in singular form. Consequently, we observe that academic research is still missing due diligence towards shared leadership. People conceive organizations as carrying single leader at the top who is the ultimate in-charge of the corporation: the CEO. If team concepts are ever taught at all, it is not with reference to the shared leadership. Business management students are thus forced, in a sense, to have a conviction that CEOs are the solo-operators. The roots of this conception are embedded in the assumptions that an individual human being must be responsible for corporate performance (Pearce \& Sims, 2000). History, however, presents a contradictory depiction as we notice that companies which depend on a single driver run a great risk: because once that person leaves organization, he takes with him the organization's ability to continue its growth prospective (Hogan, Curphy, \& Hogan, 1994). In addition, sometimes organizations, usually larger ones, carry just too much work for one person to do; even if he possesses all the necessary skills. In all such circumstances shared leadership is required, rather than banking on individual players (Jackson, 2000).

After the selection, co-leaders must cooperate (Cox, Pearce, \& Perry, 2003) and understand that the art of managing distribution of credit is more important than is to learn work. The hardest of management traits is to understand that biggest challenge is not practical or technical skills for leaders, instead, they need to learn to manage their egos, as one of the co-leaders may have to step back in certain situations (Winter, 1976).

\section{Downsides of Leadership}

Leadership carries certain risks and threats along with the positive outcomes. Generally admirable principles of leadership, if not handled properly, can end up in negative outcomes (Hoyt \& Stoner, 1968). How and why do leaders produce such negative outcomes can be based on three important skill areas of leadership. These include leaders' strategic vision, their communication and impression management skills, and their general management practices (Conger \& Ready, 2004).

Strategic vision would most probably be unsuccessful if leader's personal aims, that do not match the organization's needs, are included into it. Furthermore, a blind drive to implement personal aspirations can 
result in an inability to see environmental problems and opportunities (Zahra \& Chaples, 1993). When leader's needs and wishes diverge from those of constituents, the consequences can be quite costly. Sometimes marketplace does not simply absorb the venture because of too early and ahead of time intervention of leaders. In this case the leader may be too idealistic or too visionary so that he or she is simply unable to see that the time is yet to come, so the vision goes onto failure (Fullan, 1992). Moreover, leaders often stick to an idea and persist even if they can see the negative consequences - a problem called escalation of commitment. They simply don't want to acknowledge the flaws in their visions.

Another dark area in the field of leadership is the misuse of leaders' power (Hogg, 2004). They may present information that make their vision more appealing and realistic than reality and consequently can create a future threat for the organization. When leaders rely heavily on their impression management skills in their daily communication, they do disservice to themselves as well. (Gemmill \& Oakley, 1992). Leaders managerial skills can also become liabilities in certain cases as some leaders are reportedly notorious for their excessively impulsive and autocratic management styles. Some leaders become so troublesome through their uncommon behavior that their constituents move against them (Burke, 2006). In sum, some of the key management practices that differentiate leaders from others may also lead to their downfall (Allio, 2007).

\section{Conclusion}

Despite of the profusion of literature on the concept of leader, it continues to be an inadequately studied area and henceforth invites researchers to investigate its relatively understudied and overlooked dimensions. The stepping stone in this regard is to illustrate leadership in separation, but parallel, to the management function. Leadership, in lateral pretext, ignites with making of the self and a concrete character of leader and proliferates in lieu of the adaptation of necessary skills combining with capacity to inspire and maintain intimacy with followers. Underpinning assumptions of contemporary organizational study postulate leadership in singular perspective and thus tend to ignore that in many of the cases leadership works in acquaintance of equally eminent persons, called co - leaders. Growing complexity in contextual and structural dimensions of organization, however, is paving way towards realization that intricate affairs demand conjunction of skills and shared vision of co-leaders. It is pertinent to note that besides canvassing brighter side of the picture, powerful vision of leaders may also cause leaders to foster their personal and/or illconceived agendas.

\section{References}

Allio, R. J. (2007). Bad leaders: how they get that way and what to do about them. Strategy \& Leadership, 35(3), 12-17.

Ashkanasy, N. M., Härtel, C. E. J. \& Zerbe, W. J. (2000). Emotions in the workplace: Research, theory, and practice: Greenwood Publishing Group.

Bass, B. M., Bass, R. \& Bass, R. R. (2008). The Bass handbook of leadership: Theory, research, and managerial applications: Free Pr.

Bjerke, B. \& Hultman, C. M. (2003). A dynamic perspective on entrepreneurship, leadership and management as a proper mix for growth. International Journal of Innovation and Learning, 1(1), 72-93.

Burke, R. J. (2006). Why leaders fail: exploring the darkside. International Journal of Manpower, 27(1), 91-100.

Carmeli, A., Ben-Hador, B., Waldman, D. A. \& Rupp, D. E. (2009). How leaders cultivate social capital and nurture employee vigor: Implications for job performance. Journal of Applied Psychology, 94(6), 1553.

Conger, J. A. \& Ready, D. A. (2004). Rethinking leadership competencies. Leader to leader, 2004(32), 41-47.

Cox, J. F., Pearce, C. L., \& Perry, M. L. (2003). Toward a model of shared leadership and distributed influence in the innovation process: How shared leadership can enhance new product development team dynamics and effectiveness. Shared leadership: Reframing the hows and whys of leadership $p$ 48-76.

Eisenbach, R., Watson, K. \& Pillai, R. (1999). Transformational leadership in the context of organizational change. Journal of Organizational Change Management, 12(2), 80-89.

Fullan, M. G. (1992). Visions That Blind. Educational Leadership, 49(5), 19-22.

Fulmer, R. M. (1998). Leadership by design: Harvard Business Press. 
Gardner, W. L., Avolio, B. J., Luthans, F., May, D. R. \& Walumbwa, F. (2005). Can you see the real me?" A selfbased model of authentic leader and follower development. The Leadership Quarterly, 16(3), 343372.

Gemmill, G. \& Oakley, J. (1992). Leadership: an alienating social myth? Human Relations, 45(2), 113.

Gerstner, C. R. \& Day, D. V. (1997). Meta-Analytic review of leader-member exchange theory: Correlates and construct issues. Journal of Applied Psychology, 82(6), 827.

Gillespie, N. A. \& Mann, L. (2004). Transformational leadership and shared values: the building blocks of trust. Journal of Managerial Psychology, 19(6), 588-607.

Hogan, R., Curphy, G. J. \& Hogan, J. (1994). What we know about leadership: Effectiveness and personality. American Psychologist, 49(6), 493.

Hogg, M. A. (2004). Social Identity and Misuse of Power-The Dark Side of Leadership. Brook. L. Rev., 70, 1239.

Hollander, E. P. (1992). The Essential Interdependence of Leadership and Followership1. Current Directions in Psychological Science, 1(2), 71-75.

House, R., \& Mitchell, T. (1974). Path goal theory of leadership. Decision Making: an organizational behavior approach, 81-97.

House, R. J. (1971). A path goal theory of leader effectiveness. Administrative science quarterly, 16, 321-339.

Hoyt, G. C. \& Stoner, J. A. F. (1968). Leadership and group decisions involving risk. Journal of experimental social psychology, 4(3), 275-284.

Jackson, S. (2000). A qualitative evaluation of shared leadership barriers, drivers and recommendations. Journal of management in medicine, 14(3/4), 166-178.

Judge, T. A., Bono, J. E., Ilies, R. \& Gerhardt, M. W. (2002). Personality and leadership: A qualitative and quantitative review. Journal of Applied Psychology, 87(4), 765.

Keys, B. \& Wolfe, J. (1988). Management education and development: Current issues and emerging trends. Journal of Management, 14(2), 205-229.

Kotter, J. P. (2001). What leaders really do. 14 What Makes an Effective Executive.

Kotter, J. P. \& gestion, C. c. d. (1995). Leading change: Why transformation efforts fail. Harvard business review, 73, 59-59.

Kozlowski, S. W. J., Gully, S. M., Salas, E. \& Cannon-Bowers, J. A. (1996). Team leadership and development: Theory, principles, and guidelines for training leaders and teams.

Landy, F. J. \& Becker, W. S. (1987). Motivation theory reconsidered. Research in organizational behavior.

Lord, R. G., De Vader, C. L. \& Alliger, G. M. (1986). A meta-analysis of the relation between personality traits and leadership perceptions: An application of validity generalization procedures. Journal of Applied Psychology, 71(3), 402-410.

McCall, M. W. (1998). High flyers: Developing the next generation of leaders: Harvard Business Press.

Ng, K. Y., Ang, S. \& Chan, K. Y. (2008). Personality and leader effectiveness: A moderated mediation model of leadership self-efficacy, job demands, and job autonomy. Journal of Applied Psychology, 93(4), 733743.

0 Toole, J., Galbraith, J. \& Lawler, E. (2002). When two (or more) heads are better than one: The promise and pitfalls of shared leadership. California Management Review, 44(4), 65-83.

Pearce, C. L. \& Barkus, B. (2004). The Future of Leadership: Combining Vertical and Shared Leadership to Transform Knowledge Work [and Executive Commentary]. The Academy of Management Executive (1993-2005), 47-59.

Pearce, C. L. \& Sims, H. P. (2000). Shared leadership: Toward a multi-level theory of leadership.

Sarin, S. \& McDermott, C. (2003). The Effect of Team Leader Characteristics on Learning, Knowledge Application, and Performance of Cross Functional New Product Development Teams. Decision Sciences, 34(4), 707-739.

Townsend, R. \& Bennis, W. (1997). Reinventing Leadership: Strategies to Empower the Organization. William Morrow \& Company, New York, NY.

Van Vugt, M., Hogan, R. \& Kaiser, R. B. (2008). Leadership, followership, and evolution: Some lessons from the past. American Psychologist, 63(3), 182-196.

Winter, S. K. (1976). Developmental stages in the roles and concerns of group co-leaders. Small Group Research, 7(3), 349.

Yukl, G. A., \& Yukl, G. (2002). Leadership in organizations: Prentice Hall Upper Saddle River, NJ.

Zahra, S. A. \& Chaples, S. S. (1993). Blind spots in competitive analysis. The Academy of Management Executive (1993-2005), 7-28. 